\title{
SUGGESTIONS AND DEMONSTRATION PLANS FOR HOSPITALS FOR SICK CHILDREN*
}

\author{
BY
}

\author{
JAMES CROOKS, F.R.C.S., M.B., Ch.B., and S. E. T. CUSDIN, O.B.E., A.R.I.B.A. $\dagger$
} (From the Hospital for Sick Children, Great Ormond Street, London)

The fundamental unit in a hospital is the individual sick person. Any study of a hospital must start from consideration of the needs of the sick individual, and the complexity of a hospital is the result of the many needs of many individuals suffering from a variety of diseases. The children's hospital has three other factors which must be ever present in the minds of the organizers and designers, and which make the task of satisfying all the needs ever more difficult. They are: (1) the prevention of infection from patient to patient and from staff to patient (this aspect alone introducing elements which have a most important effect on the plan); (2) the need for constant supervision of the relatively helpless child; (3) the provision of companionship to counteract home-sickness. These three overriding problems must be faced in the ward unit, and are the crux of the problem in designing hospitals for sick children. The relationship of the ancillary departments to the ward units is, by and large, the same for general as for children's hospitals. The ward unit will, therefore, be considered first and in most detail.

The ward block at the Hospital for Sick Children, Great Ormond Street, London, has been in use for eight years, and there has, therefore, been time for criticism and assessment of the original conception of the ward unit, which represents the attempt to interpret the requirements of the Building Committee in terms of bricks and mortar. Fig. 1 is a plan of a typical ward unit of twenty beds, as at Great Ormond Street; and fig. 2 is a plan of a ward unit such as we would build now, embodying the improvements resulting from our experience in the use of the previous example, and based on the assumption that we might have a better and less congested site on which to build.

Early Wards

Before proceeding with a critical examination of the new ward unit, let us refer for a moment to earlier examples, and eliminate the features which

* Read at the Annual Meeting of the British Paediatric Association, Rugby, August 2, 1946.

+ Of Stanley Hall and Easton and Robertson, Architects. do not subscribe to our programme. Plate IIIa shows a ward built in 1862 . Several such wards were built on different floors. After seeing this photograph it is easy to understand that large wards, after the common fashion in adult hospitals of the period, were a step in the right direction.

Plate IIIb shows a large ward of thirty-five beds built in 1880 . Some time later ten or fifteen permanent beds were placed on the balcony. The aspect was east and west; the long slits of windows helped to create a large, gloomy, and overbearing ward for children. There was no attempt to prevent cross infection, and no means of controlling any outbreak of infection from spreading to thirtyfive patients. A nursing staff of probably six all had to use one room of approximately 80 sq. ft. for disposal of waste, dirty and soiled linen, mackintoshes, storage of specimens, and ward cleaning materials. Open fires radiated as much dust as heat. Treatment had to be at the bedside behind screens.

Plate IIIc shows a ward built ten years later. No appreciable change had taken place, except that the aspect was south, and the ward generally more cheerful. Plate IIId shows a similar ward of 1900, the aspect having reverted to east and west. The hoods to the cots are worthy of notice. There was more light and ventilation, but otherwise the wards remained much the same as before. It would be easy to add many other criticisms of these illustrations, but the herculean work of the staffs of that period produced miracles even under such conditions. In none of these examples was full account taken of all the three factors special to children's wards, especially the prevention of cross infection and the need for constant supervision; though provision was made in all of them for companionship.

\section{Ward units}

\section{Modern Wards}

Criticism and analysis must now be directed to the more modern experiments in the planning of the ward units, which aimed at much higher standards of hygiene, convenience, and efficiency. Returning to fig. 2, it will be seen that the ward unit is based on twenty beds under the supervision of one sister, subdivided into two sub ward units of ten beds each. Each ten-bed unit is further divided into four single-bed wards and one six-bed ward. The 
HOSPITALS FOR SICK CHILDREN

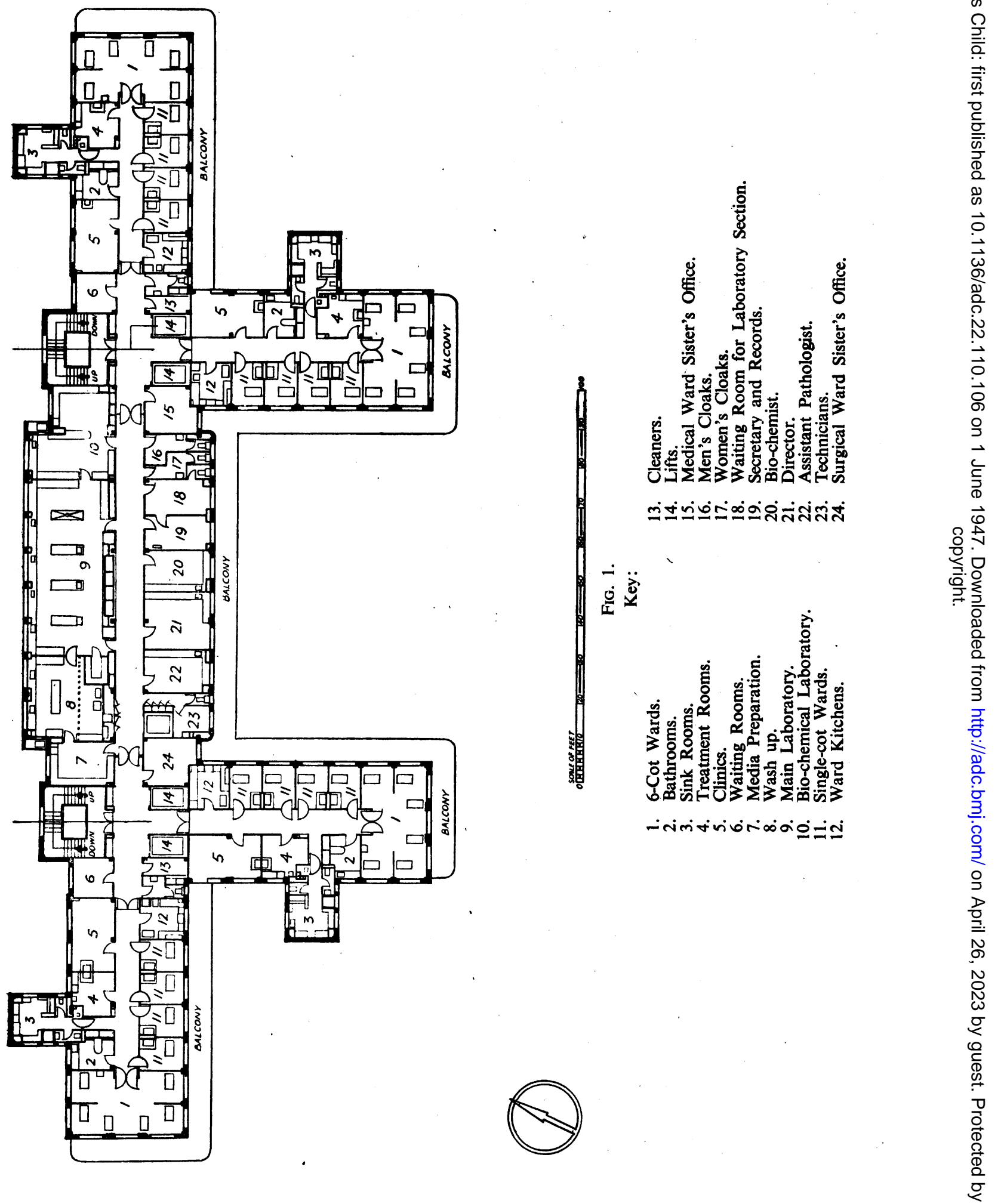




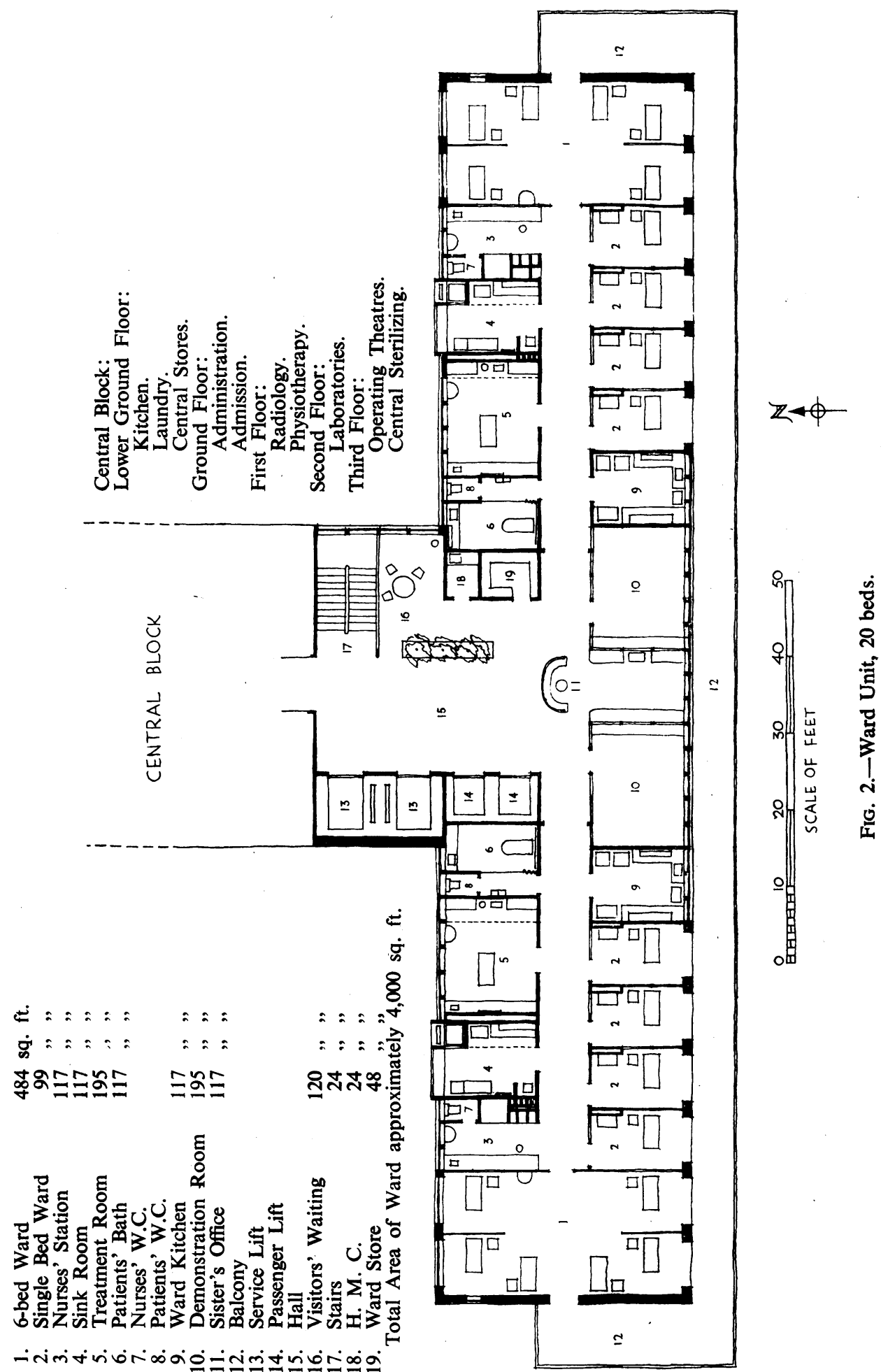


advantages claimed for this layout are: (1) prevention and control of cross infection; (2) constant supervision, by arranging for all the patients to be seen from the focal points in the units; (3) companionship, by associating patients of similar ages in six-bed wards; (4) isolation of infant, infectious or very ill cases in single-cot wards; (5) special treatments, i.e. iron lung, can be administered without disturbing other patients; (6) a flexible arrangement of patients which allows for the grouping of cases to each consultant; (7) reduction of the scale of rooms, to inspire and induce confidence in children on admission.

The main services and utility rooms are duplicated in each unit. This apparent extravagance can be justified on the following grounds: (1) in the event of an epidemic, any of the sources of cross infection are limited to ten beds: (2) the time spent by the nursing staff in movement between patients is halved, and much additional time can, therefore, be devoted to the supervision and care of patients.

The wards can now be considered in greater detail by examining each of the major rooms.

Fig. 3 shows a single-bed ward, with a south or

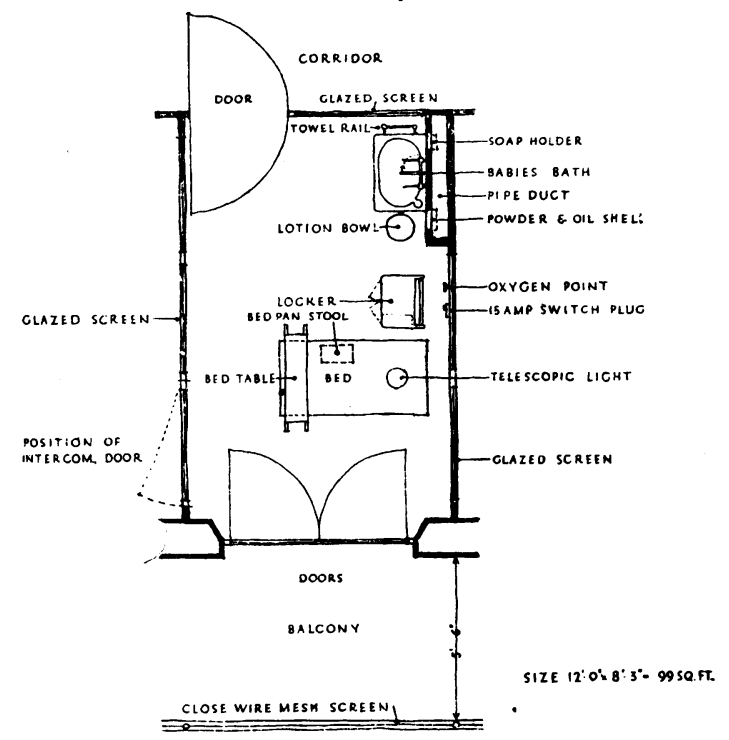

FIG. 3.-Single Cot Ward.

south-east aspect. The bed is arranged so that the patient can be approached from the right-hand side, and examined, nursed, or treated from either. There is sufficient space for a cot or bed for the older child. The area is 99 sq. $\mathrm{ft}$. This is greater than the minimum usually recognized, 70 sq. $\mathrm{ft}$., but is based on the space required round the bed for examination and nursing at the bedside. In sequence from left to right are the following facilities: (a) the surgeon's lavatory, with babies' bath, soap, lotion bowl; powder and oil, and towel rail; (b) a bedside locker, with the patient's towel, mug, tooth brush, toys, clothes, etc.; (c) oxygen point; (d) a 15 amp. power point, for portable $\mathrm{x}$-ray apparatus, cardiograph, or electric fire; (e) a bedpan stool; and (f) a bed table. There will also be the medical record card holder, the nurse's gown, curtains, and chairs. There are windows and cross ventilation; blinds are necessary; and there is a smooth run-out on to the balcony, with no steps. The balcony is $5 \mathrm{ft}$. 6 in. wide, screened to $6 \mathrm{ft} .6$ in. with a close steel mesh. Other points to be noted are: (1) the glazed screens, made of steel, flush to the wall, and cork-filled; and with plate glass, and round, easily cleaned corners; (2) the doors, a minimum of $3 \mathrm{ft}$. 3 in. wide, on check-action floor springs, with a simple bolt on the outside only, and an ample rubber kicking plate; (3) soft water, mechanical or natural, should be available as an essential requirement at all nursing points; (4) the ward can be cleaned by vacuum; (5) the walls and ceiling are finished with acoustic tiles, the floor with terrazzo; (6) the heating is by a panel in the ceiling; (7) artificial lighting by a multi-purpose telescopic fitting is suggested, the alternative choice being high-intensity fluorescent tubes.

Plate IIIe shows a single-bed ward at the Hospital for Sick Children, Great Ormond Street, and Plate IIIf a surgeon's lavatory, with babies' bath containing a recess for soap, powder, oil and thermometer; the lotion bowl, and towel rail. The lavatory is in fireclay with a surround of tiles, and the fittings fold flat to the wall. For those unfamiliar with what is meant by 'panel heating,' Plate IIIg gives an example of the system as installed at Great Ormond Street.

Plate IIIh shows the six-cot ward, which is designed to run across the full width of each end of the unit, in order to obtain direct cross-ventilation. The patients are partly isolated by glazed partitions $6 \mathrm{ft}$. 6 in. high. There is direct access to the balcony. Otherwise the services, finishes, etc., are as in the single-cot ward.

Supervision. The second of the special factors affecting the planning of the children's ward is constant supervision. It is important, therefore, that facilities should be arranged in a planned sequence so that the organization and routine of all the aspects of examination, treatment, and nursing can be accomplished with the greatest efficiency. Throughout these plans the left-to-right-hand sequence has been adopted as the basis for the arrangement of fittings and services. The most important services, or those to which there is the most traffic, are placed in the central position relative to the patient, and priority in position is given in turn according to the relative density of movement. The focal point of supervision is the nurses' station (fig. 4). From this position the nurse can see at a glance all the patients in the unit. This space is a ventilated lobby with built-in furniture, open to the corridor, and with a glazed partition to the six-bed ward. The following 


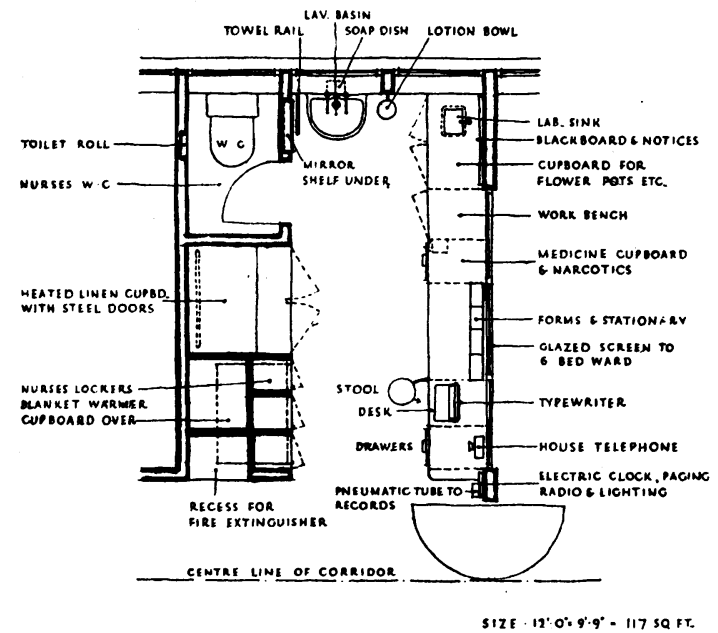

Fig. 4.-Nurses' Station.

facilities are provided: (1) a nurse's locker; (2) a recess for fire apparatus; (3) a blanket-warmer and operation clothes; (4) linen cupboards; (5) a nurse's W.C.; (6) a mirror, lavatory basin, towel rail, soap holder, and lotion bowl; (7) a notice board and blackboard; (8) poisons and narcotics; (9) facilities for the preparation of medicine; (10) a flower bench and laboratory sink, with cupboards underneath for vases, and a waste bin; (11) a writing desk and stationery holder; (12) an electric clock, pageing and lighting switches, radio control, and house telephone; (13) a pneumatic tube to the records department.

Cupboards with steel fronts are used for heated linen, and cupboards throughout should be standard units which can be easily removed for maintenance.

The sink room. Fig. 5 shows the sink room, which has been designed with a dirty side and a

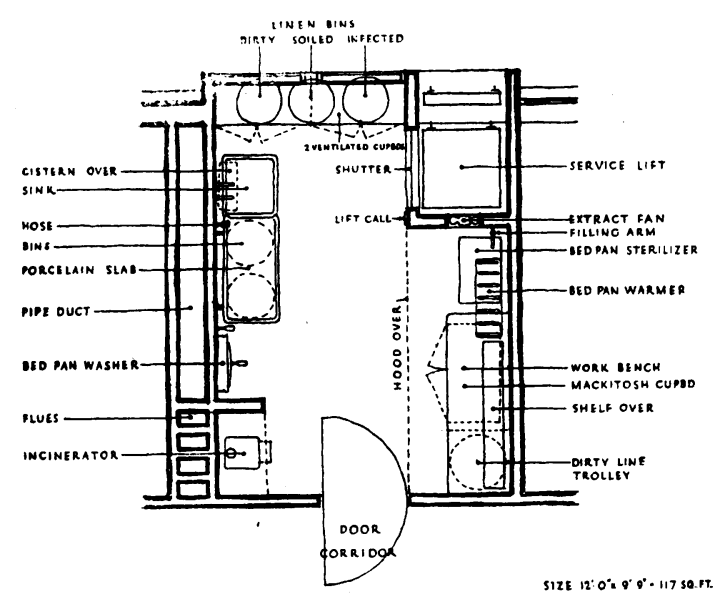

Fig. 5.-Sink Room. clean side. On the left is: (1) an incinerator for burning soiled dressings and waste; (2) a bed-pan washer of the built-in foot-operated type; (3) a porcelain slab and soil sink for washing mackintoshes, and storage racks underneath; and (4) space for a laundry trolley. It should be noted that a hood is placed over the sterilizers, and an extract fan provided to ensure the speedy evacuation of moisture-laden air and a flow of air from the corridor; a fly screen is provided to the window. Bed-pan washers are built-in. Plate IVj shows a bed-pan sterilizer and bed-pan rack. This should be contrasted with a sink room of 1880 (Plate IVk), in which all the utilities for thirty-five patients had to be carried to the one and only household sink.

Treatment room. Fig. 6 shows the treatment

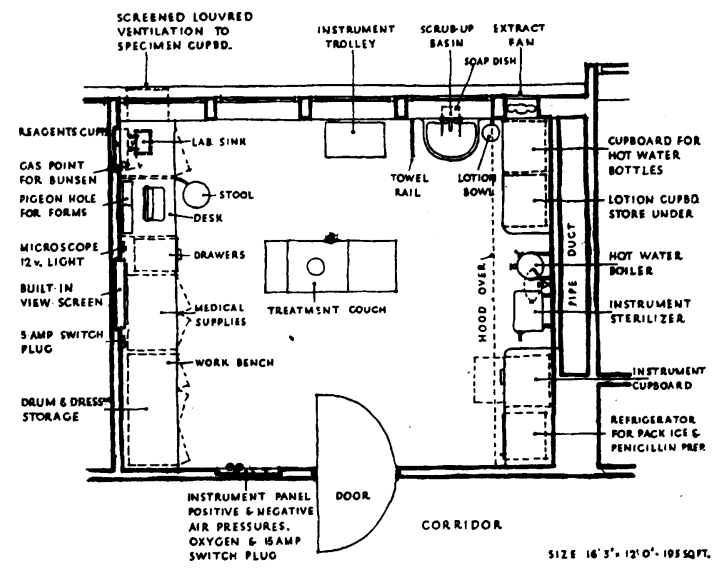

FIG. 6.-Treatment Room.

room designed for the treatment of patients, clinical examinations, and the preparation and storage of medical and surgical supplies. The couch is arranged for right-hand treatment. An instrument panel on the wall is fitted with air pressure (particularly for ear, nose, and throat wards), suction apparatus, oxygen, and a $15 \mathrm{amp}$. plug. There is a work bench with store cupboards underneath for medical and surgical supplies, dressing drums, etc.; a view box for wet and dry plates; a laboratory bench, with a bunsen sink, and a microscope point with ventilator, and cupboard beneath; a surgeon's lavatory, and the now usual accompaniment of soap holder, lotion bowl and towel rail; and lotion cupboards and hot water bottle store; a water boiler with a fomentation boiler in the top; instrument and bowl sterilizers; and a refrigerator for penicillin and pack ice.

Plate IVl shows the treatment room at the Hospital for Sick Children, Great Ormond Street. It is too small, but is indicative of the type of fittings to be used. Plate IVm shows the hot water boiler and instrument sterilizer. From our experience at Great Ormond Street the following 'do's' and 
'don'ts' in respect of sterilizers have been established: (1) don't have the steam valve under the sterilizer; (2) do have it remote; (3) don't have high pressure for normal ward use; $5 \mathrm{lb}$. is sufficient; (4) don't have any other fittings under sterilizers; (5) do have hot water filling arms; (6) do have a non-porous and well-drained floor; (7) do have mechanically lifting tray; (8) do arrange for steam to be carried away by mechanical ventilation; (9) do arrange for the valve to the waste to be readily accessible.

Bath room. Fig. 7 shows the patients' bath room

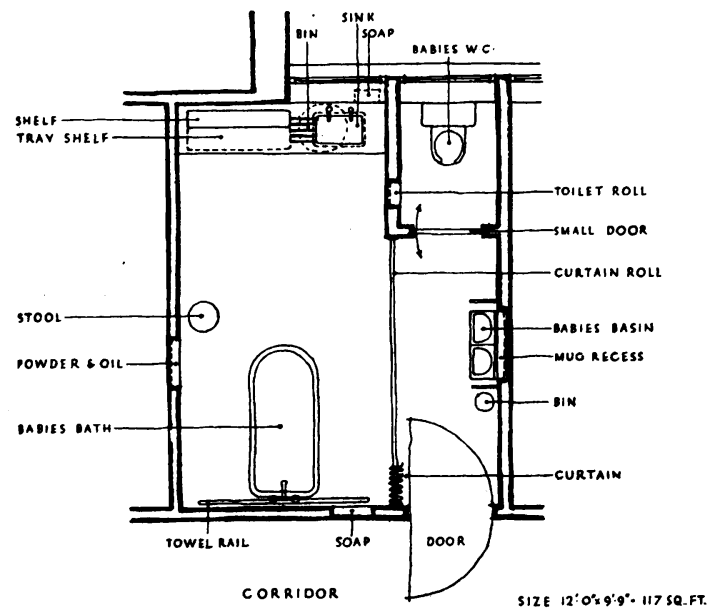

FIG. 7.-Patients' Bath.

and W.C. It is, we believe, a common arrangement for the Sister to be responsible for the washing of the patients' woollies, and facilities for this have been incorporated in this room, which includes a bath, long hot towel rail, nurses' store, powder recess, etc., a work bench with a rack underneath for trays for laying out washing bowls for patients, and a patients' W.C. and lavatory.

Fig. 8 shows the ward kitchen, where the same left-to-right sequence is maintained as kitchen specialists are advocating for domestic purposes, i.e. reception, holding, preparation, delivery: to which we must add sterilization. The ward kitchen is, therefore, laid out as follows: (1) refrigerator; (2) cooker; (3) work bench with a pot rack beneath and a shelf above, and a hot towel rail; (4) a sink with a recess for soap and solvents, and garbage cans beneath (this is the same size as the sink room); (5) a sterilizer for crockery; (6) crockery storage space, with sufficient cutlery for the trays in the drawers under the bench; (7) grocery storage space; (8) a toaster, mincer, and mixer; (9) a tray rack; (10) a notice board, and diet sheets, etc.; (11) a towel rail; and (12) a food trolley. The walls are tiled, the floor terrazzo, and the ceiling painted. There are fly screens to the windows. This plan is based on distribution of food by trolley, and would need modifying if any of the other systems of food distribution were adopted. Plate IVn shows the ward kitchen at Great Ormond Street.

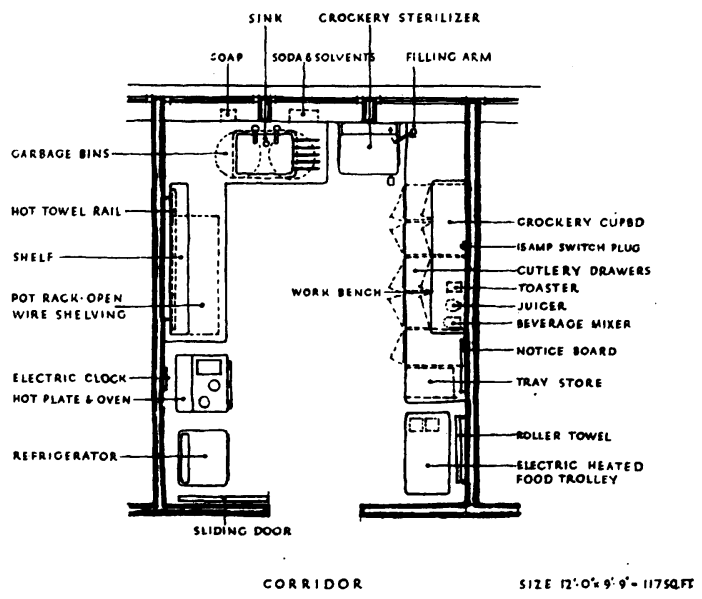

FIG. 8.-Ward Kitchen.

Demonstration room. Referring again to fig. 2, it will be seen that provision is made for a demonstration room designed as a dual-purpose room; this is particularly necessary where post-graduate teaching courses are planned. It is built (1) for teaching, with view screen and wash basin; (2) as a play room, with a south aspect, and plenty of cupboard space for storage of toys. Here children who are not bed-ridden can play under the supervision of the Sister. The Sister's office, with bow window and desk, is the control centre of the two ten-bed wards, from which the entry of staff and all visitors can be supervised. Lining each wall are bulk stock cupboards where linen, stationery and medical and surgical supplies can be kept. An enquiry desk where the Sister can interview parents is kept outside the office. The housemaid's closet and Sister's cupboard are planned in the re-entrant angle. Beside the house telephone, there is an extension from the G.P.O. switchboard to answer outside calls and enquiries about patients.

Visitors' room. The visitors' room forms part of the general circulation space, and should be easy for strangers to identify when they enter the unit for the first time in their usual forlorn state of bewilderment. To most doctors the visitors are an undesirable and unnecessary nuisance; by planning pleasant reception space for visitors it is suggested that much can be done to enhance the prestige of the hospital.

Circulation. With the above arrangement, in an area of 4,000 sq. $\mathrm{ft}$. we can nurse twenty patients and ensure that (1) we have taken action to reduce and control cross infection; (2) all patients will be under constant supervision; and (3) adequate 
arrangements have been made for companionship of the older and less ill children. The main limitations of this plan are (1) the points of support are unusual; and (2) the disposition of services is involved. The plan does not readily lend itself to superimposition on other accommodation. These limitations are overcome if the wards are planned vertically. The maximum number of beds, therefore, in any block, is 180 , as the heights of buildings are generally controlled to a maximum of $80 \mathrm{ft}$. A vertical circulation is, of course, dependent on an efficient lift service. The essential point about a lift service is that all the lifts should be concentrated in a central position so as to offer the maximum opportunity for serving callers on different floors. It is also important to arrange for separate lifts for passengers, patients, and service. A device called ' automatic collective intercept control' should be fitted, to overcome the exasperating performance of lifts continually passing the intermediate floors. The bed lifts and service lifts should be interchangeable and capable of manual operation. Lifts should be self-levelling, and the motor rooms and motor supports carefully insulated and treated to prevent transmission of noise throughout the building. Plate IVp gives an idea of the services required for a plan of this type, and shows at once how economical vertical development is achieved. Plate IVq is an external view of the ward blocks at Great Ormond Street, showing a method of expressing the balconies.

\section{Analysis of Accommodation}

In order to introduce the problems of piecing together the ancillary, administrative, and mechanical services, an appendix has been added giving schedules of accommodation for each department, together with the relative sizes of each room. The schedules have been correlated, grouped and summarized, to show the total area of the hospital divided by the number of beds for hospitals of various sizes, as follows: a forty-bed hospital, 700 sq. ft.; an eighty-bed hospital, 500 sq. ft ; a hundred and sixty-bed hospital, 460 sq. ft. ; a two hundred-bed hospital, 431 sq. $\mathrm{ft}$. It is hoped that they may be of use to those who are intending to build new wards, both in framing requirements and in giving instructions to the architect.

It will be seen from the summaries that the additional 30 sq. $\mathrm{ft}$. per bed in the single-bed wards represents a very small fraction of the total area of hospital per bed; also how relatively extravagant in floor area a small hospital of forty beds is, compared with one of two hundred beds. If plotted, the graph straightens after two hundred beds, and it is doubtful if larger hospitals can effect a saving below the 400 sq. $\mathrm{ft}$. per bed.

\section{Ancillary Departments}

It is impossible here to discuss the ancillary departments in the same detail as the wards, and a very brief reference will be made to the major problems, and to any problem peculiar to a children's hospital in these units.

Plate Vr takes us back again to the close of the nineteenth century, and shows an operating theatre of that period. It is a very good one, except that the ancillary rooms are inadequate. Plates Vs and Vt show the theatre at Great Ormond Street, whichwas planned by the hospital staff with the same open-mindedness and originality used on the ward units. It is probably not important for the theatres to be planned on the top floor. Plate Vu shows the sterilizer room.

Plate Vv shows the kitchens, which are unresolved problems in nearly all hospital plans. The greatest density and volume of inter-department movement takes place between the kitchen and the wards. The former should, therefore, be as central as possible. The choice can usually be narrowed down to a central position in a semi-ground floor or on the top floor. A better kitchen plan and circulation can be designed in the first case where freedom of space allows for difficulties arising from such a complex circulation as in the modern kitchen, e.g. the Hospital for Sick Children. A top-floor kitchen gives the best ventilation and light, both important factors in kitchen design; but the plan is handicapped by the space available for the plans of the departments underneath, for example, Westminster Hospital.

The varied dietetic requirements of many sick children create a different problem from that obtaining in an adult or general hospital. There is the addition of the milk laboratory, and the question arises whether it is economical to cook the bulk food for the staff and nurses in the same kitchen as the many individual preparations for the children, or whether it is best to divide the kitchen staff and have two separate kitchens-one for patients, the other for staff.

Plate Vw shows the laboratories at the Hospital for Sick Children, Great Ormond Street. This is another essential and important department, and a keen competitor for an area in a central position in the plan. If in this article the laboratories, radiology, and physiotherapy departments are not commented on, since there are no difficulties in planning them which are peculiar to children's hospitals, it is not to be inferred that they should not receive the closest attention and study in plan, circulation, and detail.

The out-patients' department, too, is a subject in itself, with a special claim to attention and comment from paediatricians, because the out-patient treatment of children is a different problem from that of similar treatment in a general hospital.

The hospital site, whether in town or country, will have a most important influence on the planning and inter-relationship of the various departments. It is necessary, in selecting a site, to consider : (1) accessibility for patients, visitors, staff, and personnel, and the relation of the site to public transport; (2) accessibility and circulation on the site of traffic and deliveries of supplies, bulk stores, 
and fuel; (3) availability of public utilities, such as water, electricity, gas, telephones, and sewage disposal; (4) freedom from nuisances, noise, and noxious businesses; (5) size, availability, and preservation of trees; (6) topography; (7) town planning acts relating the site to the requirements of a local region.
We should like to acknowledge the unfailing interest and many ideas which have been contributed by the physicians, surgeons, nursing and administrative staffs at the Hospital for Sick Children, Great Ormond Street, London, to the planning problems that have been discussed.

\section{APPENDIX}

TABLE 1

NURSING SERVICES: AREA DISTRIBUTION

\begin{tabular}{|c|c|c|c|c|c|c|c|c|}
\hline \multicolumn{5}{|c|}{ No. of beds } & 40 & 80 & 160 & 200 \\
\hline \multicolumn{5}{|c|}{$\begin{array}{l}\text { Patients' areas } \\
\text { (nursing units) }\end{array}$} & $\begin{array}{l}8,008 \text { sq. ft. } \\
\text { (2) }\end{array}$ & $\underset{\text { (4) }}{16,016 \text { sq. } \mathrm{ft} .}$ & $\begin{array}{c}32,032 \text { sq. ft. } \\
(8)\end{array}$ & $\begin{array}{c}40,040 \text { sq. ft. } \\
(10)\end{array}$ \\
\hline $\begin{array}{l}\text { Bed areas } \\
\text { Nurses' station } \\
\text { Sick room } \\
\text { Treatment roon } \\
\text { Bathrooms and } \\
\text { Ward kitchen } \\
\text { Demonstration } \\
\text { Sister's office } \\
\text { Visitors } \\
\text { H.M.C. } \\
\text { Stores }\end{array}$ & $\begin{array}{l}\cdots \\
\cdots \\
\text { n Patien } \\
\text { room } \\
\ldots \\
\ldots \\
\cdots \\
\cdots\end{array}$ & $\begin{array}{l}\ldots \\
\cdots \\
\ldots \\
\cdots \\
\text { ats' } \\
\ldots \\
\ldots \\
\ldots \\
\ldots \\
\ldots\end{array}$ & $\begin{array}{c}\ldots \\
\ldots \\
\ldots \\
\text { w.Cs. } \\
\ldots \\
\ldots \\
\ldots \\
\ldots \\
\ldots \\
\ldots\end{array}$ & \begin{tabular}{l|}
$\ldots$ \\
$\ldots$ \\
$\cdots$ \\
$\cdots$ \\
$\cdots$ \\
$\cdots$ \\
$\ldots$ \\
$\cdots$ \\
$\cdots$ \\
$\cdots$ \\
.
\end{tabular} & $\begin{array}{l}3,628 \\
468(4) \\
468(4) \\
792(4) \\
468(4) \\
468(4) \\
792(4) \\
468(4) \\
288(2) \\
56(2) \\
112(2)\end{array}$ & $\begin{array}{r}7,256 \\
936(8) \\
936(8) \\
1,584(8) \\
936(8) \\
936(8) \\
1,584(8) \\
936(8) \\
576(4) \\
112(4) \\
224(4)\end{array}$ & $\begin{array}{c}14,512 \\
1,872(16) \\
1,872(16) \\
3,168(16) \\
1,872(16) \\
1,872(16) \\
3,168(16) \\
1,872(16) \\
1,152(8) \\
224(8) \\
448(8)\end{array}$ & $\begin{array}{r}18,140 \\
2,340(20) \\
2,340(20) \\
3,960(20) \\
2,340(20) \\
2,340(20) \\
3,960(20) \\
2,340(20) \\
1,440(10) \\
280(10) \\
560(10)\end{array}$ \\
\hline Total & $\ldots$ & . & $\ldots$ & .. & 8,008 & 16,016 & 32,032 & 40,040 \\
\hline
\end{tabular}


TABLE 2

NURSING SERVICES (continued): AREA DISTRIBUTION

\begin{tabular}{|c|c|c|c|c|c|}
\hline \multicolumn{2}{|l|}{ No. of beds } & 40 & 80 & 160 & 200 \\
\hline \multicolumn{2}{|l|}{ Operating suite } & 1,775 sq. ft. & 2,855 sq. ft. & 3,640 sq. ft. & 4,205 sq. ft. \\
\hline 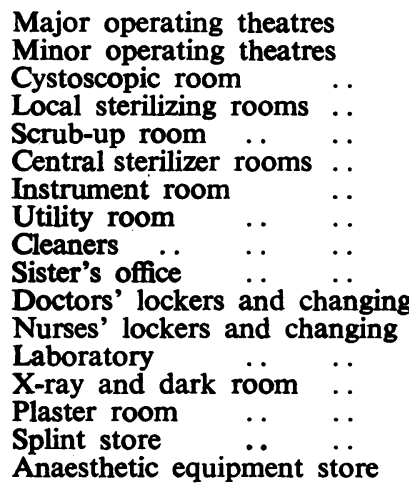 & $\begin{array}{l}\ldots \\
\cdots \\
\cdots \\
\cdots \\
\cdots \\
\cdots \\
\cdots \\
\cdots \\
\text { room } \\
\text { room } \\
\cdots \\
\cdots \\
\cdots \\
\cdots \\
\cdots\end{array}$ & $\begin{array}{l}310(1) \\
260 \\
100(1) \\
50(1) \\
400 \\
\frac{125}{20} \\
2 \overline{10} \\
160 \\
= \\
= \\
110\end{array}$ & $\begin{array}{l}620(2) \\
225 \\
150 \\
100(1) \\
90(2) \\
520 \\
125 \\
20 \\
75 \\
300 \\
160 \\
50 \\
130 \\
130 \\
50 \\
110\end{array}$ & $\begin{array}{l}930(3) \\
225 \\
150 \\
200(2) \\
100(2) \\
640 \\
100 \\
125 \\
20 \\
100 \\
350 \\
220 \\
50 \\
130 \\
130 \\
60 \\
110\end{array}$ & $\begin{array}{l}1,240(4) \\
225 \\
150 \\
200(2) \\
130(3) \\
750 \\
120 \\
125 \\
20 \\
120 \\
350 \\
280 \\
50 \\
130 \\
130 \\
75 \\
110\end{array}$ \\
\hline Total & $\ldots$ & 1,775 & 2,855 & 3,640 & 4,205 \\
\hline
\end{tabular}

TABLE 3

NURSING SERVICES (continued): AREA DISTRIBUTION

\begin{tabular}{|c|c|c|c|c|c|}
\hline No. of beds & & 40 & 80 & 160 & 200 \\
\hline Admission & & 665 sq. ft. & 730 sq. ft. & 810 sq. ft. & 830 sq. ft. \\
\hline $\begin{array}{l}\text { Admission room } \\
\text { Observation room } \ldots \\
\text { Office and waiting room } \\
\text { Bathroom } \\
\text { Lavatories and } \text { W.Cs. } \\
\text { Utility } . . \\
\text { Storage } . . \\
\text { Stretchers and trolleys }\end{array}$ & $\begin{array}{l}. . \\
\cdots \\
\cdots \\
\cdots \\
\cdots \\
\cdots\end{array}$ & $\begin{array}{r}275 \\
200 \\
\frac{60}{20} \\
\frac{65}{35}\end{array}$ & $\begin{array}{r}275 \\
200 \\
70 \\
60 \\
20 \\
70 \\
35\end{array}$ & $\begin{array}{r}275 \\
200 \\
70 \\
60 \\
20 \\
70 \\
80 \\
35\end{array}$ & $\begin{array}{r}275 \\
200 \\
70 \\
60 \\
20 \\
70 \\
100 \\
35\end{array}$ \\
\hline Total & .. & 655 & 730 & 810 & 830 \\
\hline
\end{tabular}


TABLE 4

ANCILLARY SERVICES: AREA DISTRIBUTION*

\begin{tabular}{|c|c|c|c|c|c|c|}
\hline \multicolumn{3}{|c|}{ No. of beds } & 40 & 80 & 160 & 200 \\
\hline \multicolumn{3}{|c|}{ Pathology } & 620 sq. ft. & 940 sq. ft. & 1,260 sq. ft. & 1,580 sq. ft. \\
\hline \multicolumn{3}{|c|}{ 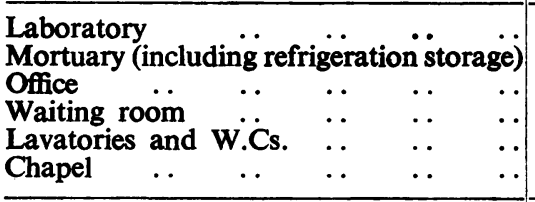 } & $\begin{array}{l}250 \\
250 \\
100 \\
\frac{20}{-}\end{array}$ & $\begin{array}{r}400 \\
300 \\
120 \\
100 \\
20 \\
-\end{array}$ & $\begin{array}{r}525 \\
325 \\
150 \\
100 \\
40 \\
120\end{array}$ & $\begin{array}{r}650 \\
350 \\
200 \\
120 \\
60 \\
200\end{array}$ \\
\hline Total & . & .. & 620 & 940 & 1,260 & 1,580 \\
\hline Radiology .. & .. & . & 400 sq. ft. & 600 sq. ft. & 850 sq. ft. & 1,200 sq. ft. \\
\hline Physiotherapy & $\ldots$ & $\ldots$ & 160 sq. ft. & 180 sq. ft. & 200 sq. ft. & 250 sq. ft. \\
\hline \multicolumn{3}{|c|}{$\begin{array}{l}\text { Pharmacy (bulk pharmacy storage in- } \\
\text { cluded in central stores area) }\end{array}$} & 185 sq. ft. & 380 sq. $\mathrm{ft}$. & 555 sq. ft. & 645 sq. ft. \\
\hline Pharmacy .. & . & .. & 185 & 260 & 260 & 260 \\
\hline Solution room & . & $\because$ & $\overline{-}$ & 120 & $\begin{array}{l}120 \\
175\end{array}$ & $\begin{array}{l}120 \\
265\end{array}$ \\
\hline Total & .. & .. & 185 & 380 & 555 & 645 \\
\hline
\end{tabular}

- No area has been given for specific research departments.

TABLE 5

ADMINISTRATION SERVICES: AREA DISTRIBUTION

\begin{tabular}{|c|c|c|c|c|c|c|c|}
\hline \multicolumn{4}{|c|}{ No. of beds } & 40 & 80 & 160 & 200 \\
\hline \multicolumn{4}{|c|}{ Administration } & 1,875 sq. ft. & 2,635 sq. ft. & 3,150 sq. ft. & 3,760 sq. $f t$. \\
\hline $\begin{array}{l}\text { Main lobby' and waitin } \\
\text { Public lavatories } \\
\text { Telephones } \\
\text { House physician } \\
\text { Social service }\end{array}$ & $\begin{array}{l}\text { ig room } \\
. . \\
\ldots \\
. \\
. \\
\text { one } \\
. \\
. . \\
. . \\
. \\
. \\
. \\
\text { room }\end{array}$ & $\begin{array}{l}\ldots \\
\ldots \\
\cdots \\
\cdots \\
\cdots \\
\cdots \\
\cdots \\
\cdots \\
\cdots \\
\cdots \\
\cdots\end{array}$ & \begin{tabular}{l|}
$\cdots$ \\
$\cdots$ \\
$\cdots$ \\
$\cdots$ \\
$\cdots$ \\
$\cdots$ \\
$\cdots$ \\
$\cdots$ \\
$\cdots$ \\
$\cdots$ \\
.. \\
$\cdots$ \\
..
\end{tabular} & $\begin{array}{r}320 \\
90 \\
10 \\
150 \\
\overline{90} \\
160 \\
125 \\
250 \\
90 \\
200 \\
140 \\
250 \\
-\end{array}$ & $\begin{array}{r}420 \\
90 \\
10 \\
150 \\
160 \\
100 \\
200 \\
125 \\
440 \\
90 \\
260 \\
160 \\
250 \\
180\end{array}$ & $\begin{array}{r}520 \\
90 \\
15 \\
150 \\
200 \\
100 \\
200 \\
125 \\
630 \\
90 \\
320 \\
260 \\
250 \\
200\end{array}$ & $\begin{array}{r}620 \\
120 \\
15 \\
150 \\
250 \\
130 \\
250 \\
125 \\
780 \\
90 \\
320 \\
320 \\
300 \\
220\end{array}$ \\
\hline Total & .. & .. & .. & 1,875 & 2,635 & 3,150 & 3,760 \\
\hline Staff facilities & .. & $\ldots$ & $\ldots$ & 580 sq. $\mathrm{ft}$. & 940 sq. ft. & 1,320 sq. ft. & 1,660 sq. ft. \\
\hline $\begin{array}{l}\text { Nurses', locker room } \\
\text { Porters' locker room } \\
\text { Female staff }\end{array}$ & $\begin{array}{l}. \\
\therefore \\
\therefore\end{array}$ & $\begin{array}{l}. \\
\cdots \\
\cdots\end{array}$ & $\begin{array}{l}\cdots \\
\cdots \\
\cdots\end{array}$ & $\begin{array}{l}320 \\
130 \\
130\end{array}$ & $\begin{array}{l}500 \\
220 \\
220\end{array}$ & $\begin{array}{l}680 \\
320 \\
320\end{array}$ & $\begin{array}{l}860 \\
400 \\
400\end{array}$ \\
\hline Total & .. & .. & .. & 580 & 940 & 1,320 & 1,660 \\
\hline Storage $\quad$ : & .. & .. & .. & 2,175 & 4,300 & 5,500 & 6,300 \\
\hline $\begin{array}{ll}\text { Record storage } & \ldots \\
{ }^{*} \text { Central lines } & \ldots\end{array}$ & . & $\because$ & 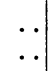 & $\begin{array}{r}175 \\
2,000\end{array}$ & $\begin{array}{r}300 \\
4,000\end{array}$ & $\begin{array}{r}500 \\
5,000\end{array}$ & $\begin{array}{r}800 \\
5,500\end{array}$ \\
\hline Total & .. & $\therefore$ &.. & 2,175 & 4,300 & 5,500 & 6,300 \\
\hline
\end{tabular}


TABLE 6

SERVICE DEPARTMENTS: AREA DISTRIBUTION

\begin{tabular}{|c|c|c|c|c|}
\hline No. of beds & 40 & 80 & 160 & 200 \\
\hline Kitchens & 2,800 sq. ft. & 3,760 sq. ft. & 5,175 sq. ft. & 6,000 sq. ft. \\
\hline 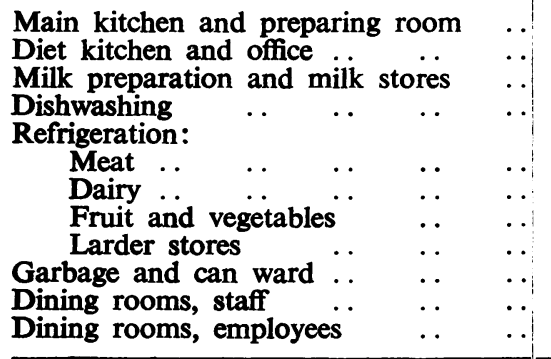 & $\begin{array}{r}1,500 \\
140 \\
130 \\
120 \\
30 \\
30 \\
30 \\
100 \\
70 \\
400 \\
250\end{array}$ & $\begin{array}{r}1,800 \\
200 \\
150 \\
170 \\
30 \\
30 \\
30 \\
150 \\
100 \\
700 \\
400\end{array}$ & $\begin{array}{r}2,500 \\
230 \\
175 \\
200 \\
30 \\
45 \\
45 \\
200 \\
150 \\
1,000 \\
600\end{array}$ & $\begin{array}{r}2,750 \\
260 \\
200 \\
250 \\
35 \\
45 \\
60 \\
250 \\
200 \\
1,200 \\
750\end{array}$ \\
\hline Total & 2,800 sq. ft. & 3,760 sq. ft. & 5,175 sq. ft. & 6,000 sq. ft. \\
\hline Housekeeper's Department .. & 1,250 sq. ft. & 2,090 sq. ft. & 2,550 sq. ft. & 3,070 sq. ft. \\
\hline 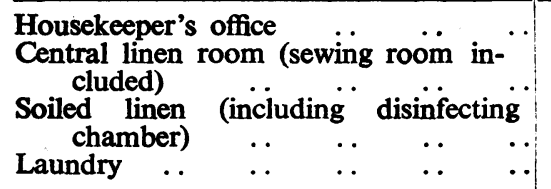 & $\begin{array}{l}110 \\
200 \\
140 \\
800\end{array}$ & $\begin{array}{r}140 \\
250 \\
200 \\
1,500\end{array}$ & $\begin{array}{r}150 \\
300 \\
300 \\
1,800\end{array}$ & $\begin{array}{r}170 \\
350 \\
350 \\
2,200\end{array}$ \\
\hline $\begin{array}{llll}\text { Total } & . . & . . & . . \\
\end{array}$ & 1,250 sq. ft. & 2,090 sq. ft. & 2,550 sq. ft. & 3,070 sq. ft. \\
\hline $\begin{array}{l}\text { Mechanical Department (no fuel storage } \\
\text { included } \\
.\end{array}$ & 1,180 sq. ft. & 1,650 sq. ft. & 1,950 sq. ft. & 2,220 sq. ft. \\
\hline \begin{tabular}{llll} 
Boiler House and & \multicolumn{2}{l}{ pump room } \\
Electrical intake & por &.. &.. \\
Engineer's office &.. & $\ldots$ &.. \\
Works $\quad .$. &.. &.. &..
\end{tabular} & $\begin{array}{r}900 \\
200\end{array}$ & $\begin{array}{r}1,200 \\
120 \\
80 \\
250\end{array}$ & $\begin{array}{r}1,400 \\
150 \\
100 \\
300\end{array}$ & $\begin{array}{r}1,500 \\
200 \\
120 \\
400\end{array}$ \\
\hline .. $\quad .$. & 1,180 & 1,650 & 1,950 & 2,220 \\
\hline
\end{tabular}

TABLE 7

CIRCULATION SPACE

\begin{tabular}{|c|c|c|c|c|c|c|c|c|c|}
\hline \multicolumn{6}{|c|}{ No. of beds } & 40 & 80 & 160 & 200 \\
\hline \multicolumn{6}{|c|}{ Circulation space* } & 5,770 sq. ft. & 9,630 sq. ft. & 13,820 sq. ft. & 15,640 sq. ft. \\
\hline $\begin{array}{l}\text { Corridors } \\
\text { Lifts } \\
\text { Stairs }\end{array}$ & $\begin{array}{l}\ldots \\
. \\
.\end{array}$ & $\begin{array}{l}. . \\
\ldots \\
. .\end{array}$ & $\begin{array}{l}\cdots \\
\cdots \\
\cdots\end{array}$ & $\begin{array}{l}\cdots \\
\cdots \\
\cdots\end{array}$ & $\begin{array}{l}. \\
. .\end{array}$ & $\begin{array}{r}4,450 \\
240 \\
1,080\end{array}$ & $\begin{array}{r}7,550 \\
640 \\
1,440\end{array}$ & $\begin{array}{r}10,700 \\
960 \\
2,160\end{array}$ & $\begin{array}{r}11,740 \\
1,200 \\
2,700\end{array}$ \\
\hline Tot & & . & $\cdots$ & . & .. & 5,770 & 9,630 & 13,820 & 15,640 \\
\hline
\end{tabular}

- These figures are approximate only and are based on two stories and lower ground floor for forty beds; 4 stories and lower ground floor for eighty beds; eight stories and lower ground floor for one hundred and sixty beds; eight stories and lower ground floor for two hundred beds. 
TABLE 8

AREA AND PERCENTAGE AREA DISTRIBUTION

\begin{tabular}{|c|c|c|c|c|c|c|c|}
\hline \multicolumn{4}{|c|}{ No. of beds } & $\begin{array}{c}40 \\
\text { Area sa ft }\end{array}$ & 80 & 160 & 200 \\
\hline $\begin{array}{l}\text { Nursing Services : } \\
\text { Patients' areas } \\
\text { Operating suite } \\
\text { Administration }\end{array}$ & $\begin{array}{l}\cdots \\
\cdots \\
\cdots\end{array}$ & $\begin{array}{l}\ldots \\
\cdots \\
\cdots\end{array}$ & $\begin{array}{l}\cdots \\
\cdots \\
\cdots\end{array}$ & $\begin{array}{r}8,008 \\
2,775 \\
665\end{array}$ & $\begin{array}{r}16,016 \\
2,855 \\
730\end{array}$ & $\begin{array}{r}32,032 \\
3,640 \\
810\end{array}$ & $\begin{array}{r}40,040 \\
4,205 \\
830\end{array}$ \\
\hline Total & . & . & .. & 10,438 & 19,601 & 36,482 & 45,075 \\
\hline $\begin{array}{c}\text { Ancillary Departme } \\
\text { Pathology } \\
\text { Radiology } \\
\text { Physiotherapy } \\
\text { Pharmacy }\end{array}$ & $\begin{array}{l}\cdots \\
\cdots \\
\cdots\end{array}$ & $\begin{array}{l}\cdots \\
\cdots \\
\cdots \\
\cdots\end{array}$ & $\begin{array}{l}. \\
\ldots \\
\ldots\end{array}$ & $\begin{array}{l}620 \\
400 \\
160 \\
185\end{array}$ & $\begin{array}{l}940 \\
600 \\
180 \\
380\end{array}$ & $\begin{array}{r}1,260 \\
850 \\
200 \\
555\end{array}$ & $\begin{array}{r}1,580 \\
1,200 \\
250 \\
645\end{array}$ \\
\hline Total & . & . & .. & 1,365 & 2,100 & 2,865 & 3,675 \\
\hline $\begin{array}{c}\text { Administration Serv } \\
\text { Administration } \\
\text { Staff facilities } \\
\text { Storage }\end{array}$ & $\begin{array}{l}. \\
\cdots \\
.\end{array}$ & $\begin{array}{l}\cdots \\
\cdots \\
.\end{array}$ & $\begin{array}{l}\ldots \\
\ldots \\
\ldots\end{array}$ & $\begin{array}{r}1,875 \\
580 \\
2,175\end{array}$ & $\begin{array}{r}2,635 \\
940 \\
4,300\end{array}$ & $\begin{array}{l}3,150 \\
1,320 \\
5,500\end{array}$ & $\begin{array}{l}3,760 \\
1,660 \\
6,300\end{array}$ \\
\hline Total & $\cdots$ & $\ldots$ & .. & 4,630 & 7,875 & 9,970 & 11,720 \\
\hline $\begin{array}{l}\text { Service Departments } \\
\text { Kitchen } \\
\text { Housekeeper's } \\
\text { Mechanical dep }\end{array}$ & $\begin{array}{l}\text { artment } \\
\text { nent }\end{array}$ & $\begin{array}{l}\ldots \\
\ldots \\
\ldots\end{array}$ & $\begin{array}{l}\cdots \\
\cdots \\
\cdots\end{array}$ & $\begin{array}{l}2,800 \\
1,250 \\
1,180\end{array}$ & $\begin{array}{l}3,760 \\
2,090 \\
1,650\end{array}$ & $\begin{array}{l}5,175 \\
2,550 \\
1,950\end{array}$ & $\begin{array}{l}6,000 \\
3,070 \\
2,220\end{array}$ \\
\hline Total & . & . & .. & 5,230 & 7,500 & 9,675 & 11,290 \\
\hline Circulation area .. & . & . & .. & 5,770 & 9,680 & 13,820 & 15,640 \\
\hline Total hospital area & & .. & . & 27,744 & 44,626 & 70,930 & 86,220 \\
\hline Area per bed & .. & .. & .. & 685 & 583 & 455 & 437 \\
\hline
\end{tabular}

DEPARTMENTS AND SERVICES NOT INCLUDED IN ANALYSIS

1. Out-Patients' and ancillary departments.

2. Doctors' private consulting rooms.

3. Research departments.

4. Students' accommodation.

5. Bath fuel stores.

6. Garages.

7. Resident doctors' quarters.

8. Nurses' home and nurses' training school.

9. Staff home.

10. Matron's quarters. 


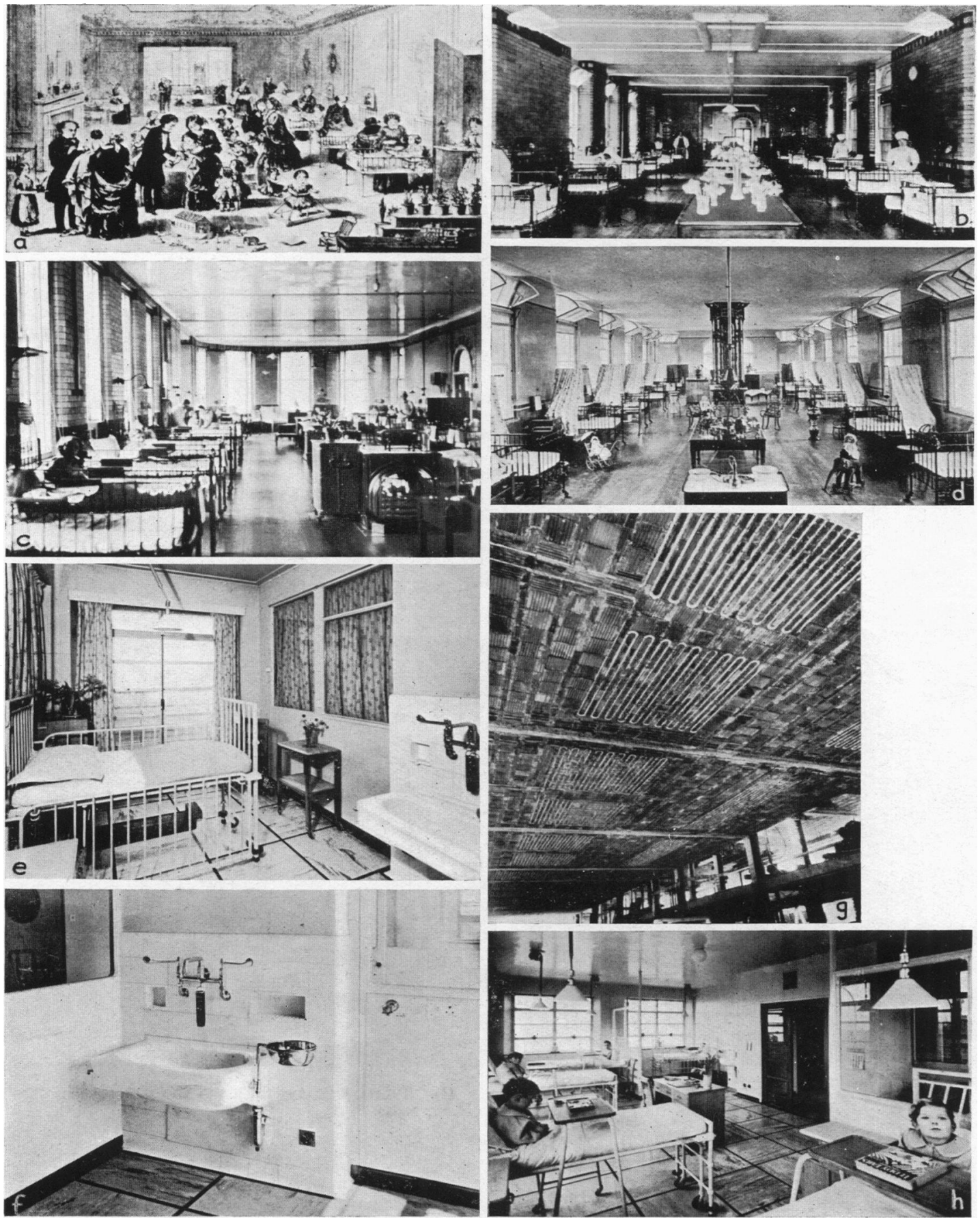


HOSPITALS FOR SICK CHILDREN BY JAMES CROOKS AND S. E. T. CUSDIN

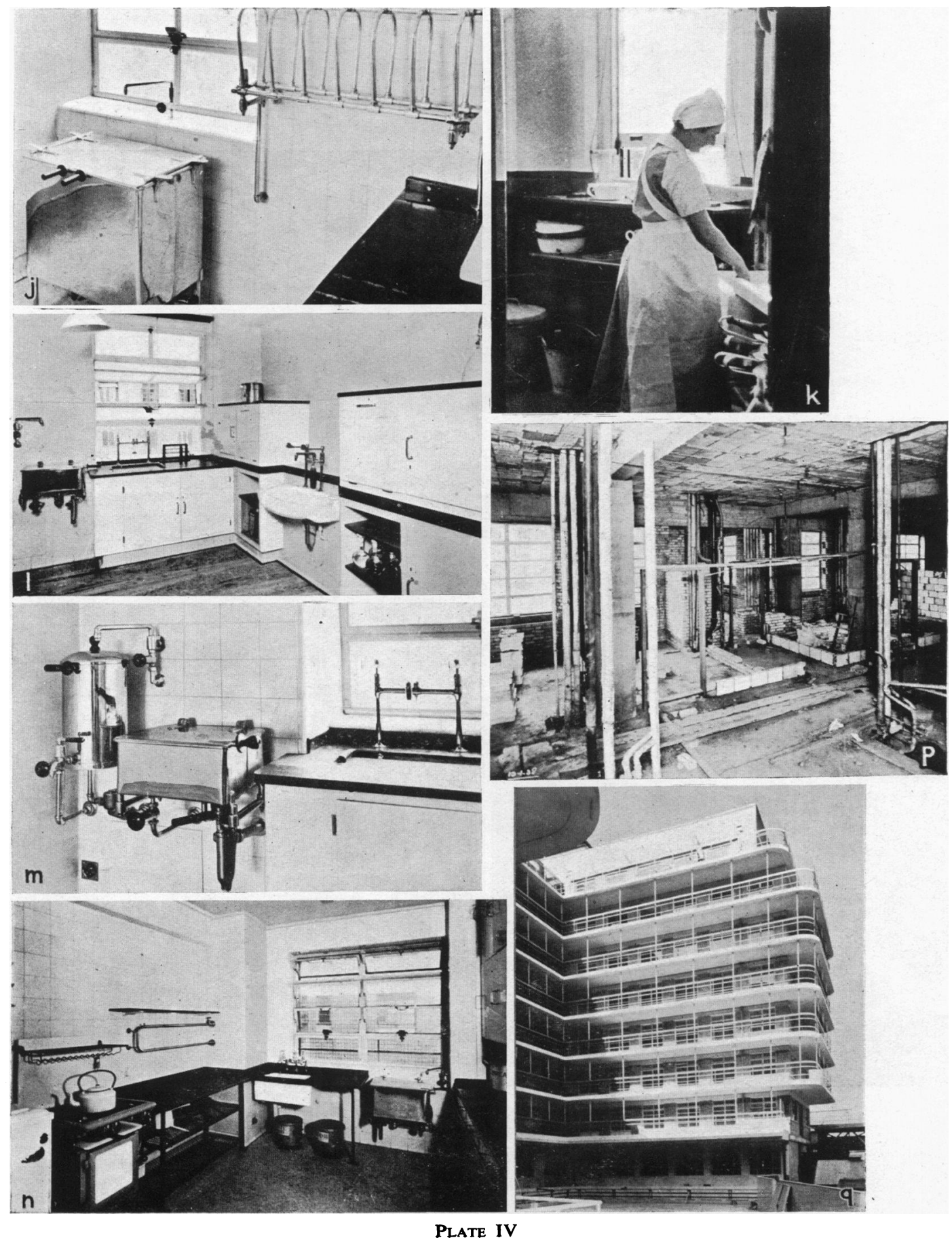

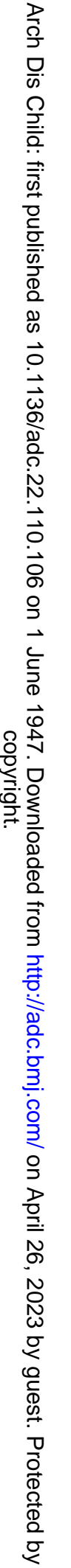



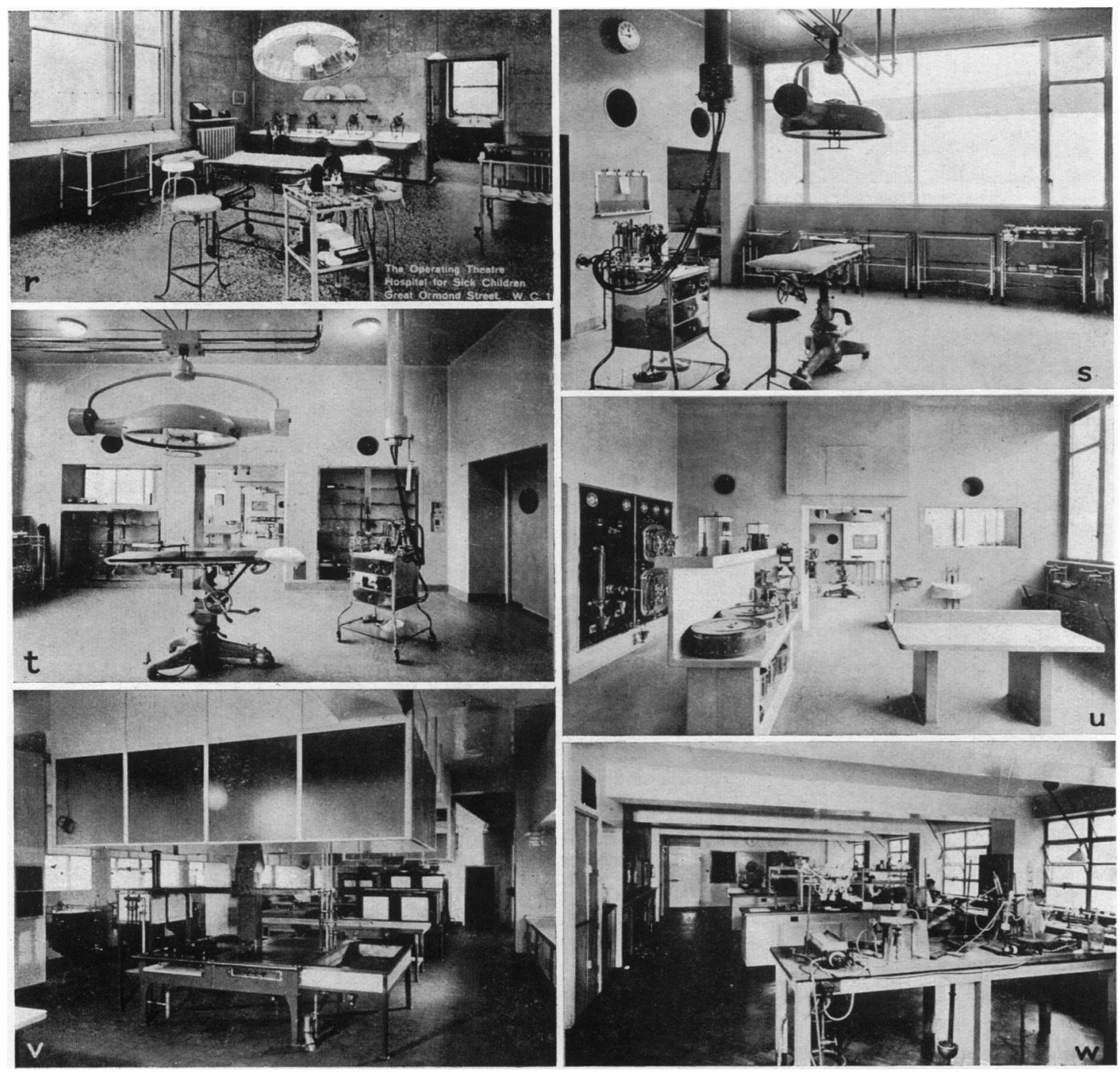

Plate V 